\title{
Financial openness: the experience of Argentina, Brazil and Mexico
}

\section{María Cristina Penido de Freitas \\ Doctor of Economics \\ (University of Paris XIII) \\ and research fellow of the \\ Administrative Development \\ Foundation of the University \\ of São Paulo \\ cpenido@fundap.sp.gov.br}

\section{Daniela Magalhães}

\section{Prates}

Candidate for Doctorate in

Economics in the Institute of

Economics of the University of

Campinas, Professor in the

Universidad Paulista, and

research fellow of the

Administrative Development

Foundation of the University

of São Paulo

dprates@fundap.sp.gov.br
This article seeks to analyse the effects of globalization on the financial systems of Argentina, Brazil and Mexico, which were the countries that received most of the foreign investment in the region in the 1990s. This capital was mostly made up of portfolio flows and investments in shares traded on the local financial systems. The movement was not homogeneous in all the countries, because of their different degrees of openness and differences in macroeconomic policies. In the case of the portfolio investments, the effects of the openness were concentrated in different segments and they therefore had different impacts on the financial systems in question. The recent experience of these countries shows that there is still some room for national economic policies to take action in the context of financial globalization, even though their capacity to reduce the perverse effects of financial flows is limited. Foreign firms are observed to be assuming growing importance in the countries studied, as a function of the degree of openness of the local financial systems. This tendency is due to the liberalization measures adopted in order to make possible capitalization of the banking systems and competition among banks to find new sources of profits and strengthen their position in globalized markets. Although the predominance of foreign companies has given a more solid capital base to the national banking systems, it could have an adverse macroeconomic impact, especially in Mexico and Brazil, which still maintain relatively independent monetary policies. 


\section{Introduction}

This article seeks to analyse the effects of globalization on the financial systems of Argentina, Brazil and Mexico, which were the countries that received most of the foreign capital invested in Latin America since the beginning of the 1990s. In the context of the return of voluntary capital flows to the region, there has been an intensification of foreign investment in the local financial markets. This consists mostly of portfolio flows: that is to say, purchases of movable assets by non-resident investors, and foreign direct investment (FDI), through the acquisition of shares on local financial markets.

For the purposes of the present article, financial globalization is defined as a process involving elimination of the segmentation of the different local financial markets, interpenetration of the local monetary and financial markets and their integration with world markets (Chesnais, 1994). The effects of this process on the local financial systems are not the same in each case, since they depend on the degree of financial openness and the way capital flows are treated by the economies. The greater the degree of financial openness -which is related with the capacity of residents to acquire securities and assume liabilities in foreign currency and the access of non-residents to the different segments of the local financial markets (Akyüz, 1992)- and the more receptive local policies are to the entry of external resources, the greater will be the influence of these flows on the respective financial systems.

The characteristics of capital flows from abroad and their effects on the financial markets of Argentina, Brazil and Mexico are studied in section II below, the expansion of foreign direct investment in local financial systems is dealt with in section III, and finally section IV presents the conclusions of this study.

\section{II}

\section{External capital flows}

This section describes the general characteristics of the recent process of financial openness in Argentina, Brazil and Mexico, with special attention to the regulatory framework which imposes discipline on the one hand on the investments made by non-residents and on the other on the monetary and financial transactions in foreign currency (or denominated in foreign currency) on local financial markets. The regulatory framework influences the composition of foreign portfolio investments -investments in public or private shares or fixed-income securities, foreign currency deposits in local banks,

$\square$ This article is a corrected and updated version of a paper presented at the Tenth Annual Conference of the Society for the Advancement of Socio-Economics (Vienna, 13-16 July 1998). The authors wish to express their thanks for the comments of an anonymous CEPAL Review referee, while naturally assuming responsibility for any errors or omissions which may still exist. or transactions in investment funds- and hence their different effects on the various segments of national financial markets.

\section{The regulatory framework}

The recent process of greater financial openness of the Latin American economies fits into a more general process of change in the international financial market and forms an integral part of the stabilization and reform programmes implemented as from the second half of the 1980s. However, the degrees of financial openness of the three countries studied here differ considerably from each other. In Argentina, the financial openness was complete. Mexico is in an intermediate position, while in Brazil there are still some restrictions on convertibility in the capital account, especially in respect of transactions in foreign currency within the national territory. 
In the 1990s, the financial openness of the Argentine economy was one of the main pillars of the monetary stabilization programme applied by the Menem administration. The Convertibility Plan provided for a fixed exchange rate regime with currency convertibility: that is to say, a currency board regime (Ferrari, 1998). In this context, the strategy adopted in order to eliminate hyperinflation and reverse the demonetization process was based on the designation of the U.S. dollar as legal tender. ${ }^{1}$ This strategy involved total freedom of capital movements between the country and the exterior, as in this type of system the monetary base is determined by the variation in the international reserves, that is to say, the inflow of liquid external resources.

Various institutional reforms made possible and stimulated the development of the dollarized segment of the Argentine economy and its financial integration with the exterior. In 1989, it was decreed that financial institutions must return deposits in the same currency in which they were originally made, and the Central Bank was denied access to those resources. In 1991, total liberalization of the foreign exchange market was achieved and the Convertibility Act was adopted (Fanelli and Machinea, 1997). In addition to establishing a fixed exchange rate parity and the convertibility of the peso with respect to the dollar, this Act authorized the denomination of contracts in any foreign currency. Total convertibility of the capital account was achieved after deregulating the capital market in 1991 -which included the elimination of the tax on stock exchange transactions and the authorization for companies and banks to issue debentures and commercial paper negotiable in foreign currency- and adopting the Fiscal Amnesty Act in 1992, which permitted the tax-free repatriation of resources held abroad by Argentine citizens (Blejer and Rozenwurcel, 1997). In 1992, with the adoption of the new Articles of Incorporation of the Central Bank, the monetary reform process was completed by establishing the independence of the Central Bank of the Argentine Republic (CBAR) and sharply restricting its capacity to provide finance for the government and to act as lender of last resort (Ferrari, 1998).

\footnotetext{
${ }^{1}$ In Argentina, there was already progressive dollarization of monetary and financial relations in the 1980 s, representing a response by the agents to chronic inflation and, in a second stage, hyperinflation (Machinea, 1996).
}

In Mexico, the recent financial openness process included the liberalization of sales of securities by non-residents and sales of public and monetary securities on the stock markets and fitted into the broader context of the reform of the national financial system begun in the late 1980s (Armella, 1993; Skiles, 1991).

The Stock Exchange Act passed in December 1989 expanded the possibilities of access to the securities market by foreign investors through the creation of a new form of investment, the "Fondo Neutro" ("Neutral Fund"), which permitted these investors to acquire Series A shares. ${ }^{2}$ Through this fund, foreign investors can acquire ordinary share certificates (CPOs), which cover the yields on the shares but not the equity rights. Up to that time, there had only been two types of foreign investment in the Mexican stock market: country funds -portfolios of shares in the most representative Mexican companies quoted on external financial markets- and freely subscribable shares (Series B shares). These shares, which were the traditional form of foreign investment in the Mexican stock market, continued to predominate even after the establishment of the Neutral Fund (Caro Razú, 1994).

The central element in the liberalization of the Mexican capital account in the 1990s was the opening up of the public securities market. The prohibition of the purchase of such securities by non-resident investors, which had been in force since 1980, was terminated in 1990 (Palomino, 1997 and Griffith-Jones, 1996). Furthermore, in December 1991, as part of the deregulation of the monetary market, transactions of Treasury Certificates (Cetes) between financial intermediaries and foreign investors were authorized (Caro Razú, 1994). These certificates are the main security traded on that market. The sale of private fixed-income securities was also liberalized.

There were two other measures which helped to establish closer links between foreign capital and the domestic financial market. One was the establishment of a simple and anonymous mechanism for repatriating resources invested abroad, subject to a flat rate tax of $1 \%$. The other was the abolition in No-

\footnotetext{
2 In Mexico, there are several different types of shares: Series A shares guarantee full control of the capital invested, while those of the other series (Series B, C and L) only offer dividends on the shares.
} 
vember 1991 of the dual exchange rate system which had been in effect since 1982. As in Argentina, the measure to provide an incentive for the repatriation of capital was of fundamental importance, in view of the magnitude of the capital flight which had taken place in the 1980s (Gurría, 1997).

The process of liberalization of the Mexican capital account was accompanied by the partial liberalization of transactions in foreign currency. From 1986 to 1991, deposits in foreign currency were only permitted for companies located near the United States border. In 1991, however, such deposits were authorized for natural persons residing in those localities and for Mexican legal persons in general. The conditions of access of non-residents to such deposits were eased somewhat in 1993, but continued to be restricted. Only official representatives of foreign governments, international organizations and foreign natural persons working for such organizations can open foreign currency deposits in Mexico. Because of these restrictions, such deposits account for only a small amount of resources and are mainly used in operations connected with foreign trade (Banxico, 1997 and 1998). As part of the domestic financial liberalization process, however, authorization was given for the issue of foreign currency-denominated securities such as the Tesobonos (very short-term 1 to 3 month Treasury bonds indexed in dollars) and bank certificates of deposit denominated in dollars (Armella, 1993).

In Brazil, foreign portfolio investments in the domestic financial market were significantly liberalized with the financial openness process of the 1990s. However, this liberalization was less pronounced than in Argentina and Mexico and affected the different markets -the money, fixed-income and stock markets- in differing ways. In the Brazilian banking system, deposits and loans in foreign currency are still prohibited for both residents and non-residents. One of the main conditions which made the application of this measure possible was the creation of indexed currency units in the 1980s (financial operations with a liquidity of one day), which, by replacing the national currency in its functions as a value reserve and unit of account, were able to prevent the dollarization of monetary and financial relations which took place, for example, in Argentina. Only a few transactions denominated in foreign currency are permitted, such as public securities indexed on the exchange rate and loans with ex- change rate correction. The relative weight of these loans in the Brazilian financial system is not yet significant, however (Prates, 1997).

Various different mechanisms were established for foreign portfolio investment, differing both in the type of instrument used -direct entry, or entry through investment funds- and in the segment of the foreign exchange market through which they are made. Up to January 1998, the official exchange market consisted of two segments: the commercial exchange market, for trade and financial transactions of strategic importance for the economy (trade balance, factor services, external debt, foreign direct investment, and the main forms of foreign portfolio investment), and the floating exchange market, on which all other operations, such as unilateral transfers, tourism, etc., were carried out (Souza, 1993).

With regard to the commercial exchange market, in May 1991 foreign institutional investors ${ }^{3}$ were given direct and unrestricted access to the domestic stock market. Access by non-resident natural persons continues to be prohibited, however. The other investment alternatives are limited to specialized investment funds, which are subject to rules regarding placement and taxation at the time when funds are brought into the country and on capital gains, although these restrictions do not apply to investments in shares. Among these specialized funds, ${ }^{4}$ the most important is the Foreign Capital Fixed-Income Fund, whose resources must be invested in fixed-income securities, with a minimum of $40 \%$ being invested in public securities.

Foreign investors also have access to the Brazilian financial market through non-resident accounts on the floating exchange market. These accounts, which are in local currency, are not subject to restrictions as regards the use to be made of the resources, and are the main means of entry of "hot money". As these flows are attracted by the spread between domestic and foreign interest rates, this form of investment was only profitable when this spread was substantial, because apart from the greater exchange risk involved -since they had to be effected on the

\footnotetext{
${ }^{3}$ Brazilian legislation defines foreign institutional investors in quite broad terms, since in addition to pension funds and insurance companies they are considered to include foreign financial establishments and foreign-based investment funds.

${ }^{4}$ The other funds are the privatization funds (for foreign capital), the investment funds in emerging enterprises, and the real estate investment funds.
} 
TABLE 1

Argentina: Monetary aggregates of the economy, 1990-1997

(Percentages)

\begin{tabular}{|c|c|c|c|c|c|c|c|c|}
\hline & 1990 & 1991 & 1992 & 1993 & 1994 & 1995 & 1996 & 1997 \\
\hline M1 as $\%$ of GDP & 2.1 & 4.3 & 5.2 & 6.0 & 6.1 & 6.7 & 7.7 & 8.6 \\
\hline $\mathrm{M} 2$ as $\%$ of GDP & 3.8 & 7.4 & 9.5 & 11.8 & 11.9 & 11.1 & 13.0 & 11.1 \\
\hline $\mathrm{M}^{\mathrm{a}}$ as $\%$ of GDP & 5.0 & 11.1 & 14.4 & 19.0 & 20.0 & 19.5 & 23.1 & $\ldots$ \\
\hline Deposits (US\$/total) & 28.0 & 45.0 & 45.0 & 47.0 & 51.0 & 54.0 & 53.9 & 53.8 \\
\hline Time deposits (US\$/total) & 30.0 & 54.0 & 54.0 & 58.0 & 65.3 & 71.9 & 72.3 & $\ldots$ \\
\hline
\end{tabular}

Source: Data of the Central Bank of the Argentine Republic, in Fanelli and Machinea (1997), Carta Económica in Meyer (1997a) and Carta Económica in Ferrari (1998).

${ }^{\mathrm{a}}$ Includes deposits in dollars.

floating market- they were subject to higher rates of tax. Other than having to pay a higher rate of the tax on financial transactions, these operations received the same fiscal treatment as in the case of residents and were even subject to the provisional withholding tax on financial movements.

Through these mechanisms, the prevailing regulatory framework sought to select the capital flows effected on the commercial exchange market by establishing specific forms of application for variable-income and fixed-income investments. At the same time, an instrument was established for the floating exchange market with the aim of absorbing the most highly speculative external resources. ${ }^{5}$

\section{The impact of foreign portfolio investments on Latin American financial markets}

The impact of foreign portfolio investments on Latin American financial markets varies according to the different degrees of financial openness, the specific characteristics of each financial system, and the different options for the macroeconomic management of these flows. A fundamental aspect is that of the forms these investments take in domestic financial markets which have been liberalized. Portfolio investments involve considerable financial risks for the peripheral countries, especially in terms of possible exchange or banking crises. These risks depend both

${ }^{5}$ In February 2000 the Brazilian Government decided to do away with the differential treatment for variable-income and fixed-income investments and authorized portfolio investments by physical persons in the Brazilian stock market. These changes, which came into force on 31 March 2000, increased the financial openness of the Brazilian economy and thus reduced the differences in terms of openness with the other countries analysed here. on the term of the investments and on their characteristics: fixed-income or equity investments and short, medium or long-term flows (Basle Committee on Banking Supervision, 1995).

In Argentina, the Central Bank does not maintain detailed records of portfolio flows to the domestic financial market, but in general portfolio investments correspond to the unspecified capital movements registered in the "other movements" item of the balance of payments (Fanelli and Machinea, 1997).

The demand for financial assets and the degree of monetization of the Argentine economy began to recover in 1991, after the adoption of the Convertibility Plan, when capital flows changed direction (table 1). Both residents and non-residents used deposits in dollars to bring resources into the country. In this way, they protected themselves against the risk of devaluation and took advantage of the prevailing high domestic interest rates. The remainder of the capital flows went to the local stock exchanges (Fanelli and Machinea, 1997).

The inflow of capital played a fundamental role in the remonetization process and the recovery of the level of financial intermediation The stabilization process and the adoption of currency convertibility were not reflected in any substantial recovery in the demand for national currency, however: on the contrary, they increased the degree of dollarization, as foreign-currency deposits came to predominate (Machinea, 1996).

The expansion of the dollarized segment was not accompanied by a corresponding increase in the term of deposits, which continued to be concentrated on a 30-day term. Because of the larger amount of foreign-currency finance, loans in dollars predominated. The relative share of such loans amounted to $58 \%$ of 


\begin{tabular}{|c|c|c|c|c|c|c|c|c|c|c|c|c|}
\hline \multirow{4}{*}{ Year } & \multicolumn{12}{|c|}{$\begin{array}{l}\text { Mexico: Foreign portfolio investments in the Mexican financial market, 1991-1997 } \\
\text { (Millions of dollars) }\end{array}$} \\
\hline & \multirow{2}{*}{\multicolumn{2}{|c|}{ ADR markets }} & \multicolumn{3}{|c|}{ Stocks } & \multicolumn{6}{|c|}{ Government securities } & \multirow{3}{*}{ Total } \\
\hline & & & \multicolumn{2}{|c|}{$\begin{array}{l}\text { Mexican stock } \\
\text { market }^{\text {a }}\end{array}$} & \multirow[t]{2}{*}{ Total } & \multicolumn{2}{|c|}{ Cetes } & \multicolumn{2}{|c|}{ Tesobones } & \multicolumn{2}{|c|}{ Other } & \\
\hline & $\begin{array}{c}\text { Total } \\
\text { amount }\end{array}$ & $\begin{array}{l}\% \\
\text { total }\end{array}$ & $\begin{array}{c}\text { Total } \\
\text { amount }\end{array}$ & $\begin{array}{c}\% \\
\text { total }\end{array}$ & & $\begin{array}{c}\text { Total } \\
\text { amount }\end{array}$ & $\begin{array}{c}\% \\
\text { total }\end{array}$ & $\begin{array}{c}\text { Total } \\
\text { amount }\end{array}$ & $\begin{array}{l}\% \\
\text { total }\end{array}$ & $\begin{array}{c}\text { Total } \\
\text { amount }\end{array}$ & $\begin{array}{l}\% \\
\text { total }\end{array}$ & \\
\hline 1991 & 13.7 & 73.9 & 4.9 & 26.1 & 18.6 & 3.0 & 54.0 & 0.3 & 4.7 & 2.2 & 41.3 & 5.5 \\
\hline 1992 & 21.2 & 73.8 & 7.5 & 26.2 & 28.7 & 9.2 & 64.3 & 0.2 & 1.4 & 4.8 & 34.3 & 14.2 \\
\hline 1993 & 34.0 & 62.2 & 20.6 & 37.8 & 54.6 & 15.4 & 70.2 & 1.3 & 5.9 & 5.2 & 23.9 & 21.9 \\
\hline 1994 & 21.2 & 61.6 & 13.2 & 38.4 & 34.4 & 2.5 & 12.3 & 17.4 & 85.0 & 0.6 & 2.7 & 20.5 \\
\hline 1995 & 15.2 & 62.1 & 9.3 & 37.9 & 24.5 & 2.8 & 82.0 & 0.2 & 5.6 & 0.4 & 12.4 & 3.4 \\
\hline 1996 & 15.1 & 48.8 & 15.9 & 51.2 & 31.0 & 3.0 & 89.2 & 0.0 & 0.0 & 0.4 & 10.8 & 3.4 \\
\hline 1997 & 23.1 & 47.2 & 25.7 & 52.5 & 48.8 & 3.0 & 90.3 & 0.0 & 0.0 & 0.3 & 90.7 & 3.3 \\
\hline
\end{tabular}

Source: BANXICO, 1998.

a Includes freely tradeable shares, "Neutral Fund" and country funds.

the total in 1994, compared with $40 \%$ in 1991 (Ferrari, 1998). These resources went mainly to production activities for the domestic market and finance for the purchase of consumer durables (Blejer and Rozenwurcel, 1997). Thus, the vulnerability of the Argentine financial system to the reversal of capital flows, which was inherent in the convertibility system, was further heightened by the liquidity of deposits in dollars (and in pesos) and the concentration of loans in the non-tradeable sectors, which increased the exposure of the banks' portfolios to exchange rate devaluation. The absence of a lender of last resort further accentuated this vulnerability, which became very evident with the Mexican crisis in December 1994. The outflow of capital due to the "tequila effect" was reflected in a serious banking crisis in the first half of 1995 and a profound economic recession.

It may be noted that the macroeconomic management applied under the domestic convertibility system presupposes a significant degree of receptiveness to capital flows. Under this system, the inflow of capital does not affect exchange and monetary policies -and is not therefore reflected in an increase in the public debt- but it is reflected in an increase in dollar deposits in the banks, which stimulates domestic demand and economic activity.

In Mexico, foreign portfolio investments represented over $60 \%$ of the capital flows received by the country between 1990 and 1994. These flows went in particular to the purchase of shares and Mexican government paper (table 2). Deposits in the banking system, such as time deposits and bank certificates denominated in foreign currency, were not very significant. The segment of the Mexican financial market most affected by the financial openness process was the public securities market. In the case of the stock market, the impact of foreign portfolio investments was less marked because, up to 1995, most of the stocks were acquired through the use of American Depositary Receipts (ADRs). There was thus a transfer of liquidity to the United States securities exchanges, especially the New York Stock Exchange. In Mexico and Argentina, the flight from the local securities exchanges was heightened by the use of ADR programmes in the privatization process. The aim of these programmes was to reduce the possibility of saturation of the local market because of the large volume of the stocks traded compared with the size of those exchanges (ECLAC, 1995).

The large volume of foreign investments in public securities, until the outbreak of the Mexican crisis at the end of 1994, was the main special feature of Mexico in comparison with the other countries studied. Between 1990 and 1994, these operations accounted for $55 \%$ of total foreign portfolio investments. Between 1991 and 1993, non-residents absorbed the greater part of new issues of public securities, especially short-term ones, and their share of total Mexican public debt rose from $8 \%$ at the end of 1990 to $57 \%$ at the end of 1993 (Griffith-Jones, 1996).

In 1994 there was a significant change in the composition of the public debt in the hands of for- 
eign investors. Treasury Certificates (Cetes), which are denominated in pesos, systematically took the place of Tesobonos, which were very short-term securities indexed in dollars (table 2). After February of that year, because of the rise in United States interest rates and the exchange risk associated with the upward trend of the current account deficit, the premium demanded by foreign investors for maintaining their holdings of Cetes increased considerably. In order to avoid an excessive increase in the cost of rolling over the public debt and an outflow of capital, the government began to offer Tesobonos to non-resident investors. As a result, by mid-1994 those investors held $80 \%$ of the total amount of such bonds outside the banking system (Goldestein and Turner, 1996).

The experience of Mexico shows the negative effects that can result from opening up the public debt securities market to foreign investors, especially when those securities are short-term and denominated in foreign currency. The Tesobonos market was one of the main focal points of the 1994 exchange crisis. ${ }^{6}$ The volume of those securities held by non-residents, which exceeded the size of the international reserves, increased the vulnerability of the balance of payments and the public accounts to a possible reorientation of capital flows. In view of the growing mistrust about the Mexican government's capacity to meet its liabilities in respect of those securities, foreign investors proceeded to sell off their holdings. As the reserves were only small compared with the magnitude of the capital flight, the Central Bank was unable to contain the exchange crisis and had to opt for a floating exchange rate. Furthermore, the public sector was faced with the need to refinance a large volume of short-term debts in dollars, whose local-currency value had risen because of the currency devaluation.

It may be noted that much of the increase in the public debt was associated with the monetary policy of partial sterilization of the inflow of external resources. By avoiding a drop in domestic interest rates, this policy encouraged capital inflows, but as the pub- lic debt was acquired by non-residents the policy of sterilization did not do anything to reduce the vulnerability of the economy and the financial system to capital flows. On the contrary, this strategy heightened the external fragility of the Mexican economy. Apart from the sterilization policy, the more flexible exchange policy adopted (including the introduction of exchange-rate bands in 1991) and the fiscal surpluses achieved helped to partly offset the monetary impact of the external resources (Gurría, 1997).

In Brazil, almost all the foreign portfolio investors operated on the São Paulo stock exchange (Bovespa), the most important of the country. The amounts of external resources procured through investment funds were not significant. Only the Foreign Capital Fixed-Income Fund (FRFCE) attracted a fairly substantial amount of resources at the times of biggest interest rate spreads, mainly in public debt securities indexed on the exchange rate (similar to the Mexican Tesobonos). Investments made through non-resident accounts also went mainly to these securities, although the total volume in the hands of non-residents continues to be small.

As a result, the effects of the financial openness were concentrated in the secondary securities market. Unlike what happened in Mexico, up to 1997 the number of ADR programmes of Brazilian companies was small both in absolute terms and in comparison with the other Latin American countries, and the market value of the shares traded on the ADR market was equivalent to only $6.5 \%$ of the capital value of Bovespa's operations in December 1997 (Freitas and Prates, 1999). This is explained by the size of the Brazilian market, which has a higher level of capitalization and hence greater liquidity than the Mexican market. Moreover, in Brazil the privatization process has not so far involved the issue of ADRs. The share of foreign investors in the total amount traded on Bovespa has increased significantly in recent years, from $6.5 \%$ in 1991 to $29.4 \%$ in 1995 . Along with the growth of this share there has also been a continual increase in the volumes traded and the capital value of the market (table 3$)^{7}$

\footnotetext{
6 The other focal point was the banking system, because the banks held large amounts of short-term liabilities in foreign currency and part of them were guaranteed by Tesobonos. With regard to the Mexican banking crisis, see Griffith-Jones (1996) and Folkerts-Landau, Mathieson and Schinasi (1997).
}

\footnotetext{
${ }^{7}$ It may be noted that the increase of over $100 \%$ between 1996 and 1997 in the volume traded was due to the privatization of Vale do Rio Doce and several State-owned electric power companies. These movements were also stimulated by the progress in the privatization of the Telebras and Eletrobras systems.
} 
TABLE 3

Brazil: Participation by foreign investors in the São Paulo stock exchange, 1991-1997

\begin{tabular}{|c|c|c|c|c|}
\hline Year & Foreign investment $^{a}$ & Total amount traded ${ }^{b}$ & $\begin{array}{c}\text { Capital turnover of the } \\
\text { market }{ }^{b}\end{array}$ & Main stock traded ${ }^{\mathrm{c}}$ \\
\hline 1991 & 6.0 & 28.4 & 43615.1 & 41.3 \\
\hline 1993 & 16.0 & 96.4 & 99430.1 & 50.2 \\
\hline 1994 & 21.4 & 303.6 & 189058.2 & 40.1 \\
\hline 1995 & 29.4 & 233.3 & 147560.0 & 49.8 \\
\hline 1996 & 28.6 & 356.0 & 216927.0 & 61.2 \\
\hline 1997 & 25.9 & 786.7 & 255409.0 & 55.86 \\
\hline
\end{tabular}

Source: BOVESPA, Revista Mensual, various issues.

${ }^{\text {a }}$ Foreign participation as a percentage of the total volume traded.

${ }^{\mathrm{b}}$ Millions of dollars.

${ }^{\mathrm{c}}$ As a percentage of the total volume traded.

In contrast, however, the financial openness did not help to reduce the degree of concentration of the secondary market or to boost the primary securities market. Purchases by foreign investors were concentrated in the stock of State enterprises in the process of privatization (especially Telebras -Brazilian Telecommunications), because of the prospect of an increase in their value once they had been privatized. Because of this, the market value and liquidity of shares in private companies continued to be low, thus discouraging demand by investors and new stock issues. The low volume of primary issues meant that the shares of those companies accounted for a smaller relative share of the secondary market, thus increasing the concentration of transactions in more liquid securities (Prates, 1999).
Although portfolio investments in shares are less volatile than fixed-income investments, because of the greater risk of capital loss, these investments also involve financial risks for the peripheral countries. Because of the large volume of capital flows compared with the size of the stock markets, the rearrangement of their portfolios by foreign investors has a strong impact on share prices (Akyüz, 1992). The effects of these movements on the Brazilian stock market were clearly visible during the Mexican and Asian crises. On those two occasions -in the first quarter of 1996 and the last quarter of 1997- stock prices fell sharply because of the sale of their holdings by foreign investors to cover their losses on other emerging markets or to increase their provisions for covering possible withdrawals by their clients.

\section{III}

\section{The growth of foreign direct investments in national financial systems}

During the 1990s the financial markets of the Latin American countries also attracted foreign direct investment in the form of equity participation in local financial intermediation companies or the installation of new branches or subsidiaries totally controlled by foreign financial institutions. On the one hand, this tendency was fostered by the new competitive strategies of financial institutions in the industrialized countries, marked by the elimination of barriers between the activities of banks and non-bank financial 
institutions and the concentration and centralization of capital in national markets through mergers and acquisitions, while the process was also facilitated by the abolition or easing of restrictions in a number of countries and the establishment of subsidiaries or branches of foreign institutions in local markets, the participation of non-residents in the equity of local institutions, and the activities of foreign financial intermediaries in local markets. These measures to liberalize the treatment accorded to foreign financial institutions were adopted both by the industrialized and by the peripheral countries (Freitas, 1999).

The increase in competition in the local markets of the central countries prompted banks and other financial intermediaries to seek new areas for making profits. In their efforts to strengthen their global positions, financial institutions opted for the geographical diversification of their activities through the establishment of branches or subsidiaries in foreign countries. The main difference between this process and the internationalization of the 1960s and 1970s is that the strategies of support for transnational enterprises and the supply of external finance which prevailed at that time gave way to a strategy of diversification of activities in the local markets of the host countries. This process calls for denser networks and greater integration of the foreign institutions into the local banking system.

Apart from the need to diversify outside their own saturated local markets, the recent entry of important financial groups into the region has also been stimulated by the stability of the Latin American economies, the prospect of numerous profitable business opportunities, and the existence in most cases of relatively weaker local competitors. The Spanish-speaking countries were the first targets for direct investments by these groups, but in the second half of the 1980s it was Brazil's turn. Indeed, the Brazilian market came to be the most highly prized in the region, as it offered the possibility of big profits for the foreign banks that set up operations there.

In this section, we will analyse the recent expansion of banking institutions in Argentina, Brazil and Mexico. We will begin by looking at the changes made in the legal and regulatory treatment given to foreign capital, after which we will analyse the expansion strategies adopted by foreign banks in those three countries and the results of their activities.

\section{Changes in the legal treatment given to foreign capital}

The three countries analysed here have different features as regards the legal treatment given to foreign institutions. Whereas the regulatory environment in Argentina was more favourable for those institutions, in Mexico and Brazil the prevailing conditions for the establishment of branches by non-resident institutions and for participation in the equity of local institutions were more restrictive. This accounts for the different degrees of openness and liberalization.

In Argentina, the openness of the local financial system was promoted as part of the 1977 financial reforms, when all restrictions on the entry of new institutions and the expansion of bank networks were abolished, both for local and foreign institutions (Feldman and Sommer, 1984). In practice, the Argentine legislation adopted the principle of according foreign banks the same treatment as local ones, so that they were subject to the same rules, or rules that were no less favourable. This legislation also expanded the range of permissible activities for all banks.

The non-discriminatory treatment given to foreign capital made possible the recent denationalization of the Argentine financial system. As from 1997, foreign institutions -which occupied only modest positions in the local market in the period of high inflation- embarked on a series of total or partial purchases of local banks. At present, with the exception of the two big public banks -the Banco de la Nación and the Banco de la Provincia de Buenos Aires- and one private bank (Banco Galicia y Buenos Aires), all the main Argentine banks are controlled by non-residents.

The three biggest private banks controlled by non-residents have continually increased their market shares, with the introduction of new products (Folkerts-Landau, Mathieson and Schinasi, 1997, p. 161). The concentration of the Argentine banking system is also reflected in the total number of institutions, which went down from 205 in December 1994 to 138 in December 1997.

In Mexico, the entry of foreign banks was prohibited until the 1990s. These institutions were only allowed to be present as representation offices, with a very limited field of activity, since they could not carry out any financial intermediation operations 
whatever. Furthermore, from the nationalization of the banking system in 1981 up to its privatization in the early 1990s, the establishment of new institutions was prohibited even for residents.

In July 1990, with the entry into force of a new law on credit institutions, the conditions of access of foreign financial institutions to the local financial system began to be eased. Under this law, the Ministry of Finance and Public Credit, which is responsible for the regulation of financial institutions, was empowered to authorize the establishment of agencies of foreign banks in the country. These branches could only operate with non-residents, however (Ferreira and others, 1998). At the same time, minority foreign participation in the equity of brokerage houses was also authorized.

In April 1994, under the terms of the North American Free Trade Agreement, rules were adopted on the establishment of Mexican branches of foreign financial institutions, authorizing the direct opening of branches of United States and Canadian banks and stockbroking firms and the formation of ten foreign financial groups, six of which included a bank. In addition, thirteen branches of foreign insurance companies were authorized to operate in the country (Palomino, 1997).

A further easing of the restrictions on foreign banks in Mexico took place in the context of the serious crisis in the banking system in 1994. With the aim of shoring up the capital of institutions damaged by the crisis, the legislation on the structure of the equity of banks and holding companies of financial groups was reformulated in February 1995 to permit the participation of foreign legal persons (Banxico, 1996). Non-residents were authorized to acquire series $\mathrm{B}$ and $\mathrm{L}$ shares up to an individual limit of $20 \%$ of the equity of Mexican institutions. This limit could be increased, however, if a branch of a foreign bank gained control of a local bank by purchasing all the series A shares. In order to prevent the biggest banks from being acquired by foreign institutions, the Ministry of Finance and Public Credit laid down that no individual foreign bank could own more than $6 \%$ of the total assets of the domestic banking system (Meyer, 1997b).

It should be noted that the Mexican Government authorized foreign institutions to participate in the privatization of the banking system. Their participation was limited to $30 \%$ of the total capital, however, with an individual ceiling of $5 \%$ for each investor. At the end of 1998 the Mexican Congress did away with this restriction, thus making possible majority foreign control of national commercial banks, including the three largest: Banamex, Bancomer and Serfin (Taylor, 1999).

In Brazil, except for the period from 1946 to 1964 , when there was complete freedom of access of foreign institutions to the local financial system, there have always been restrictive rules, either on the entry of foreign banks or on the conditions under which they can operate on the local market. From the 1965 financial reforms up to 1995, foreign direct investment in the banking system and the range of activities foreign banks were allowed to engage in depended on the principle of reciprocity. Under this approach, the Brazilian Government only permitted the entry of banks from countries which likewise permitted the access of Brazilian banks to their financial systems. Representation offices could be freely established throughout this period, however.

After the 1988 Constitution came into force, the access of foreign capital to the financial system was virtually prohibited, since it depended on the formulation by Congress of a regulatory framework for which the corresponding regulations have still not been adopted. However, article 52 of the Transitory Constitutional Provisions did leave open the possibility of the entry of foreign institutions into the Brazilian market through authorizations resulting from international agreements involving the principle of reciprocity, as a counterpart for the establishment of branches of Brazilian banks abroad, or in circumstances considered by the government to involve the "national interest". Applications were to be examined on a case-by-case basis, subject to the final approval of the President of the Republic.

In August 1995, taking advantage of this prerogative, the government declared, in Exposition of Motives No. 311, that it was in the country's interest to permit the entry or expansion of foreign participation in the national financial system. This decision was taken in the light of the growing fragility of the national financial system, which had been affected by an abrupt contraction of liquidity due to the restrictive economic measures adopted to cope with the impact of the Mexican crisis. The opening up of the financial system also satisfied the desires of many foreign financial institutions 
and represented a partial concession to the demands expressed in many international forums, such as the World Trade Organization, MERCOSUR and the Free Trade Area of the Americas.

The opening up of the capital market, the privatization and industrial restructuring processes, and the possible business opportunities associated with financing the renewal of the economic infrastructure were the main attractions for foreign direct investment in the Brazilian financial system. Various financial institutions showed great interest in operating in the country in order to take advantage of the big possibilities for business and profits that existed, especially in the investment banking sector. The growth potential of retail trade and bank accounts was also a big attraction for the foreign banks, both those that were only now entering the market and those that were already established in the country. Whereas there is only one bank for every 4,500 persons in Brazil, in Germany there is one for every 2,000, and in Spain, one for every 1,100 persons (The Economist, 1998, p. 61).

The announcement of the government's decision to authorize foreign participation in the equity of local private institutions and in the privatization of the public banks, as well as to allow the establishment of new foreign subsidiaries, stimulated the interest of foreign institutions in entering the local financial market. As from August 1995, there was a considerable increase in the contacts between local banks and foreign institutions interested in associating with them, acquiring a majority share of their equity or even buying them outright.

This movement took on such proportions that the Central Bank began to demand that institutions requesting authorization to enter the market or expand their activities should pay a kind of "toll" as a contribution to the public resources used to put the financial system on a sound footing, except when the foreign institutions were acquiring banks that were insolvent or in serious financial difficulties (Freitas, 1999).

These measures to ease the conditions for the entry or functioning of foreign banks have been highly recommended to developing country governments by the representatives of multilateral agencies such as the International Monetary Fund or the World Bank. In the view of these official agencies, greater participation by foreign capital in local banking systems will help to strengthen the ability of the latter to weather macroeconomic crises, as possible difficulties of the local subsidiaries of foreign banks will not automatically cause them to go bankrupt. In addition, it is expected that, through the introduction of "greater competition", foreign financial capital will solve the main shortcomings of local financial markets, such as their high spreads and costs compared with international levels, the high concentration of risks, and the existence of restricted markets.

\section{The expansion strategies of foreign banks}

In order to diversify their activities abroad, banks adopt various expansion strategies in keeping with the regulatory and legal framework of the host country. For new arrivals, the choice lies between opening a totally controlled local branch or subsidiary or acquiring equity participation in a local institution. Foreign banks which are already present in the country usually prefer either gradual growth through the establishment of a network of branches to expand their business base, or an aggressive policy of purchasing market shares by absorbing their competitors. The form of expansion adopted is closely related to the range of institutions existing in the different markets. This typology can be used to analyse the recent expansion of foreign banks' activities in Latin America.

As may be seen from table 4, in Mexico foreign banks took advantage of the more flexible access conditions applied after the 1995 financial crisis to acquire shares in the equity of the local institutions placed under the control of the local supervisory body, the National Banking and Securities Commission, and/or financed by FOBAPROA, the bank deposit guarantee fund. In Brazil, some foreign institutions also opted to acquire equity control of local banks, while others preferred to set up branches or subsidiaries.

With regard to the expansion of banks already present in the region, an examination of recent trends shows that in Argentina the preferred method used by foreign institutions to strengthen their positions in the local market was the absorption or purchase of majority shares in local banks (table 5). In Brazil, the oldest-established banks in the country, such as Lloyds Bank and the ABN-Amro Bank, adopted different expansion strategies. In Mexico, the local subsidiary of Citibank -the only survivor of the 
TABLE 4

Brazil and Mexico: Main participants in the banking internationalization process, 1995-1998

\begin{tabular}{|c|c|c|c|}
\hline Host country & Institution & Country of origin & Manner of entry \\
\hline \multirow[t]{6}{*}{ Brazil } & $\begin{array}{l}\text { Hong Kong and Shanghai } \\
\text { Banking Corporation (HSBC) }\end{array}$ & United Kingdom & $\begin{array}{l}\text { Acquisition of the assets of the Banco Bamerindus } \\
\text { (bankrupt) }\end{array}$ \\
\hline & Groupe Crédit Suisse & Switzerland & Acquisition of the Banco Garantía \\
\hline & Nations Bank & United States & Acquisition of $51 \%$ of the equity of the Banco Liberal \\
\hline & United Bank of Switzerland & Switzerland & Establishment of a wholly-owned subsidiary \\
\hline & Banco Bilbao Vizcaya (BBV) & Spain & $\begin{array}{l}\text { Acquisition of the Banco Excel-Económico } \\
\text { (bankrupt) }\end{array}$ \\
\hline & Rabobank & Netherlands & Establishment of a branch \\
\hline \multirow[t]{7}{*}{ Mexico } & Banco Bilbao Vizcaya (BBV) & Spain & Acquisition of $70 \%$ of the Probusa group \\
\hline & Bank of Nova Scotia & Canada & Acquisition of $45 \%$ of the equity of the Banco Inverlat \\
\hline & Bank of Montreal & Canada & Acquisition of $16 \%$ of Bancomer \\
\hline & A.G. Alemania & Germany & $\begin{array}{l}\text { Acquisition of control of the Banco Banoro and } \\
\text { Bancrecer }\end{array}$ \\
\hline & Banco Santander & Spain & $\begin{array}{l}\text { Establishment of subsidiaries and acquisition of } \\
51 \% \text { of the equity of the Banco Mexicano }\end{array}$ \\
\hline & $\begin{array}{l}\text { Hong Kong and Shanghai } \\
\text { Banking Corporation (HSBC) }\end{array}$ & United Kingdom & $\begin{array}{l}\text { Acquisition of } 20 \% \text { of the equity of the } \\
\text { Serfin group }\end{array}$ \\
\hline & $\begin{array}{l}\text { Banco Central } \\
\text { Hispano }\end{array}$ & Spain & $\begin{array}{l}\text { Acquisition of } 10 \% \text { of the equity of the Prima } \\
\text { International group }\end{array}$ \\
\hline
\end{tabular}

Source: Conger (1998); Freitas (1999); Warner (1995 and 1998); Del Villar and others (1997); Taylor (1997a and b); The Banker (1997a ); Cypher (1996).

nationalization process of the 1980s- acquired the Confia bank in August 1997. This bank had been intervened by the Central Bank because of its irregular activities abroad (The Banker, 1997b, p. 46).

In the three countries analysed, the aggressive strategies adopted by Spanish banks, and also by new rivals such as the Hong Kong and Shanghai Banking Corporation (HSBC), forced the foreign banks which had already been established in the region for a long time to take defensive measures. Some of them opted to expand their networks of branches, as BankBoston did in Brazil and Argentina, while others -such as Bankers Trust in Argentina and Lloyds Bank, Chase Manhattan and ABN-Amro in Brazil- decided to buy local banks or shares in their equity.

The result of this recent internationalization process suggests that foreign institutions are likely to take on growing importance in the local financial markets of the countries analysed. The rate of expansion of the foreign banking presence varies considerably from one country to another, however. Between December 1994 and December 1998, foreign participation in the local financial systems increased more rapidly in Mexico than in Brazil and Argentina (table 6). In Mexico, this expansion was very substantial: at the end of 1998, foreign banks possessed $40 \%$ of the market compared with only $1.2 \%$ in 1994. The advance of foreign banks was also considerable in Brazil, especially in 1997 and 1998. In Argentina, the latest figures available are for 1997, but it may be assumed that foreign participation has increased in 1998 because the process of acquisition of local banks has continued.

The different rates of internationalization reflect the heterogeneity of the regulatory frameworks existing in each country. As it is the most open, the Argentine banking system is most likely to register a further increase in foreign participation. In Mexico, some legal restrictions which limit the expansion possibilities of financial institutions are still in force, despite the new financial law approved by Congress at the end of 1998. Brazil is in an intermediate position, as the legal loophole opened by the government may be closed if Congress finally decides to adopt financial system legislation which restores the limitations pre- 
TABLE 5

\section{Latin America: Examples of the recent expansion of foreign banks}

\begin{tabular}{|c|c|c|c|}
\hline Host country & Institution & Country of origin & Manner of expansion \\
\hline \multirow[t]{9}{*}{ Argentina } & Hong Kong and Shanghai & United Kingdom & Acquisition of $100 \%$ of the Banco Roberts \\
\hline & Banking Corporation (HSBC) & & \\
\hline & BankBoston & United States & Expansion of network of branches \\
\hline & Banco Santander & Spain & $\begin{array}{l}\text { Acquisition of } 51 \% \text { of the equity of the Banco } \\
\text { Río de la Plata }\end{array}$ \\
\hline & Bank of Nova Scotia & Canada & $\begin{array}{l}\text { Increase from } 25 \% \text { to } 100 \% \text { of participation in the } \\
\text { equity of the Banco Quilmes }\end{array}$ \\
\hline & Grupo Socimer & Switzerland & $\begin{array}{l}\text { Acquisition of } 30 \% \text { of the equity of the } \\
\text { Banco Patricios }\end{array}$ \\
\hline & Bankers Trust & United States & $\begin{array}{l}\text { Acquisition of } 51 \% \text { of the Banco Liniers } \\
\text { Sudamericano }\end{array}$ \\
\hline & Crédit Agricole & France & Acquisition of $1 / 3$ of the equity of the Banco Bisel \\
\hline & Banco Bilbao Vizcaya (BBV) & Spain & $\begin{array}{l}\text { Merger of the Banco Francés del Río de la Plata, } \\
\text { controlled by BBV, with the Banco de Crédito } \\
\text { Argentino }\end{array}$ \\
\hline \multirow[t]{7}{*}{ Brazil } & Citibank & United States & Expansion of network of branches \\
\hline & BankBoston & United States & Expansion of network of branches \\
\hline & Banco Santander & Spain & $\begin{array}{l}\text { Acquisition of } 51 \% \text { of the equity of the Banco } \\
\text { Geral do Comércio and of the Banco Noroeste }\end{array}$ \\
\hline & Lloyds Bank & United Kingdom & $\begin{array}{l}\text { Acquisition of the Banco Multiplic and its finance } \\
\text { company }\end{array}$ \\
\hline & ABN-Amro Bank & Netherlands & Acquisition of $40 \%$ of the equity of the Banco Real \\
\hline & Chase Manhattan & United States & Acquisition of the Banco Patrimônio \\
\hline & Banque Nationale de Paris (BNP) & France & Acquisition of the Banco FonteCindam \\
\hline Mexico & Citibank & United States & Acquisition of the Banco Confia \\
\hline
\end{tabular}

Source: Conger (1998); Freitas (1999); Warner (1995 and 1998); Taylor (1997a and b); The Banker (1997a and b).

TABLE 6

Argentina, Brazil and Mexico: Evolution of foreign participation in the local financial systems

\begin{tabular}{lccc}
\hline & \multicolumn{2}{c}{$\begin{array}{c}\text { Foreign-owned assets, as a percentage of } \\
\text { the total assets of the banking system }\end{array}$} \\
\cline { 2 - 4 } Country & $\begin{array}{c}\text { December } \\
1994\end{array}$ & $\begin{array}{c}\text { December } \\
1997\end{array}$ & $\begin{array}{c}\text { December } \\
1998\end{array}$ \\
& 21.7 & 45.0 & $\ldots$ \\
Argentina & 11.0 & 21.1 & 22.5 \\
Brazil & 1.2 & 19.9 & 40.0 \\
Mexico & & & \\
\hline
\end{tabular}

Source: Goldenstein and Turner (1996); Palomino (1997); Folkerts-Landau, Mathieson and Schinasi (1997, p. 165); The Economist (1997); KPMG Peat Marwick (1998), and Conger (1999). viously in force under the pressure of influential local banking interests.

Differences in the institutional aspects of finances in these three countries also undoubtedly help 
TABLE 7

Situation of the ten largest Argentine, Brazilian and

Mexican banks in December 1997

\begin{tabular}{|c|c|c|c|c|c|}
\hline \multirow{2}{*}{ Institution } & \multirow{2}{*}{ Country } & \multirow{2}{*}{ Ownership } & \multirow{2}{*}{$\begin{array}{c}\text { Capital } \\
\text { (millions of } \\
\text { dollars) }\end{array}$} & \multicolumn{2}{|c|}{ Ranking } \\
\hline & & & & Latin America ${ }^{a}$ & World $^{b}$ \\
\hline Banco do Brasil & Brazil & Public & 5562 & 1 & 63 \\
\hline Bradesco & Brazil & Private & 5481 & 2 & 65 \\
\hline Itaú & Brazil & Private & 3893 & 3 & 99 \\
\hline Unibanco & Brazil & Private & 2373 & 4 & 145 \\
\hline Banespa & Brazil & Public & 2350 & 5 & 147 \\
\hline Nación Argentina & Argentina & Public & 2002 & 6 & 166 \\
\hline Banamex & Mexico & Private & 1790 & 7 & 181 \\
\hline Bancomer & Mexico & Private & 1659 & 8 & 196 \\
\hline Banco Real & Brazil & Private & 1581 & 9 & 200 \\
\hline Provincia de Buenos Aires & Argentina & Public & 1223 & 10 & 238 \\
\hline \multicolumn{6}{|l|}{ Compared with: } \\
\hline \multicolumn{6}{|l|}{ Hong Kong and Shanghai } \\
\hline Banking Corporation (HSBC) & United Kingdom & Private & 27392 & - & 1 \\
\hline Citicorp & United States & Private & 22211 & - & 4 \\
\hline ABN-Amro & Netherlands & Private & 15864 & - & 8 \\
\hline Nations Bank & United States & Private & 13599 & - & 13 \\
\hline Santander & Spain & Private & 7952 & - & 40 \\
\hline Bank of Nova Scotia & Canada & Private & 6820 & - & 49 \\
\hline Banco Bilbao Vizcaya & Spain & Private & 6800 & - & 50 \\
\hline
\end{tabular}

Source: The Banker (1998).

a The 25 largest banks, according to their capital, excluding wholly-owned subsidiaries of foreign banks.

b The 1,000 largest banks, according to their capital.

to explain the greater or lesser success that foreign banks have had in gaining positions in the local markets. Thus, for example, Argentine and Mexican banks are smaller than those of Brazil. Of the ten biggest Latin American banks in December 1997, six were Brazilian, three were Argentine, and only one was Mexican (table 7). In addition to their extensive networks of branches, Brazilian banks also use sophisticated technologies for electronic transfers of funds and resource management. These technologies, which were developed in a period of high inflation, will help them to keep their clients and avoid the financial dis-intermediation suffered by Argentine and Mexican banks, while they also place them (especially in the case of the big banks) in a position to compete with the foreign banks operating in the country.

Compared with the other Latin American banks, the Brazilian banks also benefit from the fact that the national banking system has not gone through any pro- 
found, generalized crises in recent decades. Furthermore, the local banking institutions are not viewed with mistrust by the public: on the contrary, public banks attract more clients than the private institutions when the financial situation becomes more delicate.

The most vulnerable aspect of the Brazilian banks is their relatively small volume of capital

\section{IV}

\section{Conclusions}

As we have tried to show, the impact of foreign investments (portfolio and direct) on the Latin American financial markets varies according to the different degrees of financial openness, the specific institutional characteristics of each national financial system, and the different macroeconomic management options with regard to external capital flows.

In the three countries studied here, the profile of portfolio investments in the local financial markets was determined by the different financial openness policies, influenced (among other factors) by the monetary stabilization strategies adopted, which also determined the different degrees of freedom of macroeconomic management with regard to capital flows. In Argentina, the adoption of a stabilization plan based on a currency board system meant the total financial openness of the economy. In Mexico and Brazil, the anti-inflation policies followed did not call for the complete liberalization of the capital account and the adoption of currency convertibility. Furthermore, the exchange-rate and monetary system in force after stabilization (exchange-rate bands) allowed some leeway for the macroeconomic management of capital flows through expansion of the exchange-rate fluctuation band in order to discourage the entry of short-term flows and the sterilization of capital inflows through the issue of public securities.

The effects of the opening-up of local financial markets were concentrated in different segments: in the money market in Argentina, in the public securities market in Mexico, and in the secondary stock market in Brazil. For this reason, the impacts of foreign direct investment on the national financial systems and, ultimately, on the economy as a whole, differed both in terms of the moments of abundance and the changes in direction of those flows. The up- compared with the foreign banks. This is also true of the Argentine and Mexican banks. Indeed, the HSBC alone has more capital than the ten biggest Latin American banks put together (table 7). In the countries where such actions are permitted, the local banks are extremely vulnerable to the threat of a hostile takeover by foreign institutions. sets caused by a capital flight due to the sudden withdrawal of non-residents' bank deposits (which are generally used to finance domestic credit operations) are, potentially, much more harmful than those associated with the massive sale of shares by foreign investors, because in Latin America there is little integration between the credit and stock markets (either through cross-participation or through the use of such documents as loan collateral). Consequently, the repercussions of financial openness on the peripheral economies also depend on the structural characteristics of the national financial systems.

In spite of the common features of the economic policy strategies of the three countries analysed -stabilization plans with an exchange-rate anchor, financial and trade openness, privatization, etc.- the experience of Argentina, Mexico and Brazil in the 1990s shows that there is still some leeway for national policies in the context of the present financial globalization. Those policies can reduce the financial risks associated with foreign portfolio investment, as those risks are directly related with the nature of capital flows and their maturities.

With regard to the local financial systems, there is a trend towards the growing importance of foreign institutions in the financial markets of the three countries in question. This trend is due, above all, to the liberalization measures taken by the governments to bring capital into their weakened bank finance systems. This greater foreign participation is also due to the competitive strategies of the banks themselves, which are trying to find new sources of profits and to strengthen their positions in increasingly globalized markets.

Contrary to the claims of the multilateral organizations, which advocate opening up the financial sys- 
tems of the developing countries to foreign institutions, there is no guarantee that the entry of new competitors will be reflected in lower credit rates and costs. The entry of new institutions and the increase in the foreign presence in the countries studied is basically motivated by the desire to make big profits. In this respect, even though they may have competitive advantages over the local banks it is hard to imagine the foreign institutions forgoing high incomes by reducing their rates and margins. Where this does happen, it is rather a question of short-term marketing strategies than of a lasting policy. Moreover, competition in terms of prices is only one of the various competitive strategies of a banking institution. The possible positive impact of greater foreign participation on the cost of banking services and the financial conditions of the local economies, as well as on the quality of the banking services offered to the public, remains to be seen. It is an unknown quantity, and only time will tell.

There is, however, one aspect that is worth mentioning as a beneficial consequence of greater participation by foreign banks, namely, the increased financial solidity of the national banking systems. There can be no doubt that stronger institutions have a greater capacity to withstand macroeconomic shocks, thus reducing the possibility of systemic crises.

Nevertheless, the possibility of migration of resources to foreign banks in the event of capital flight, as a safety measure by the public in the face of the possible insolvency of a major domestic private bank, would undoubtedly have harmful effects on macroeconomic management in countries like Brazil and Mexico, which still enjoy relative monetary sovereignty because they have not adopted the currency board system. In a context marked by the predominance of foreign institutions, the monetary authorities would have the greatest difficulty in handling the liquidity conditions of the system. The Brazilian authorities faced a situation of this type in 1995, when the rise in domestic interest rates in response to the adverse reactions to the Mexican crisis profoundly affected the local banking system. With the rise in interest rates and the increase in the number of bad debts, the banks became more selective, thus complicating the refinancing of non-financial debtors and of the banking institutions most dependent on inter-bank transactions. On that occasion, the preference of the private banks (both domestic and foreign) for liquidity cancelled out the Central Bank's efforts to reactivate the inter-bank market. Had it not been for the aid of the main public banks, which acted as lenders of last resort for the banks which were having difficulties, the financial fragility of the banking system could have got worse and set off a generalized crisis. This experience suggests that it is important for developing countries to have a mixed banking system in which well-managed public banks coexist with domestic and foreign private banks and aid in achieving the objectives of government policy.

(Original: Portuguese)

\section{Bibliography}

Akyüz, Y. (1992): On Financial Openness in Developing Countries, Geneva, United Nations Conference on Trade and Development (UNCTAD).

Armella, P. (1993): El camino mexicano de la transformación económica, Mexico City, Fondo de Cultura Económica (FCE).

Banxico (Banco de México) (several years): Informe anual, Mexico City.

-(1996): Informe anual, Mexico City. (1997): Informe anual, Mexico City. (1998): Informe anual, Mexico City.

BIS (Basle Committee on Banking Supervision) (1995): 65th Annual Report, Basle, June.

Blejer, L. and G. Rozenwurcel (1997): El sistema bancario argentino en los noventa: de la profun- dización financiera a la crisis sistémica, Desarrollo económico, vol. 37, No. 146, Buenos Aires, Instituto de Desarrollo Económico y Social (IDES).

Borio, E. and R. Filosa (1995): The changing borders of banking: trends and implications, in The Financial Landscape: Forces Shaping the Revolution in Banking. Risk Management and Capital Markets, Paris, Organization for Economic Cooperation and Development (OECD).

Bouzas, R. and R. Ffrench-Davis (1998): Globalization and governance in the developing countries, CEPAL Review, special issue, LC/G.2037-P, Santiago, Chile, Economic Commission for Latin America and the Caribbean (ECLAC), October. 
BOVESPA (Bolsa de Valores de São Paulo) (several issues): Revista BOVESPA, São Paulo.

Caro Razú, E. C. (1994): Acceso a los mercados internacionales de capital y desarrollo de instrumentos financieros: el caso de México, "Financiamiento del Desarrollo" series, No. 18, Santiago, Chile, ECLAC, June.

Chesnais, F. (1994): La mondialisation du capital, Paris, Syros.

Conger, L. (1998): Santander's Latin American crusade, Institutional Investor, vol. XXIV, No. 1, New York, Institutional Investor Inc., January.

(1999): Participação estrangeira no México deve crescer, Gazeta mercantil Latino-Americana, ano 4, No. 155, 12-18 April.

Cypher, J. (1996): Mexico: Financial fragility or structural crisis?, Journal of Economic Issues, vol. XXX, No. 2, Sacramento, California, Association for Evolutionary Economics, June.

Del Villar, R. and others (1997): Experiencia internacional en la resolución de crisis bancarias, Documento de investigación, No. 9708, Mexico City, BANXICO, December.

ECLAC (1995): Latin America and the Caribbean: Policies to improve linkages with the global economy, LC/G.1800/Rev.1-P, Santiago, Chile, United Nations publication, Sales No. E.95.II.G.6.

Fanelli, J. M. and J. Machinea (1997): O movimento de capitais na Argentina, in R. Ffrench-Davis and S. Griffith-Jones (eds.), Os fluxos financeiros na América Latina: um desafio ao progresso, Río de Janeiro, Editora Paz e Terra.

Feldman, E. and J. Sommer (1984): Crisis financiera y endeudamiento externo: consecuencias de la política económica del período 1976-1981, Buenos Aires, Centro de Economía Transnacional (CET).

Ferrari, A. (1998): O plano de convertibilidade argentino, Campinas, Brazil, State University at Campinas, Institute of Economcs, Master's thesis.

Ferreira, C.K.L. and others (1998): O formato institucional do sistema monetário e financeiro: um estudo comparado, in M. A. M. Cintra and M.C.P. Freitas (eds.), Transformações institucionais dos sistemas financeiros: um estudo comparado, São Paulo, Administrative Development Foundation.

Ffrench-Davis, R and S. Griffith-Jones (eds.) (1997): Os fluxos financeiros na América Latina: um desafio ao progresso, Río de Janeiro, Editora Paz e Terra.

Folkerts-Landau, D., D.J. Mathieson and G.J. Schinasi (1997): International Capital Markets: Developments, Prospects and Key Policy Issues, Washington, D. C., Intemational Monetary Fund (IMF), November.

Freitas, M.C.P. (1997): Concurrence bancaire, spéculation et instabilité fmancière: une lecture hétérodoxe de l'évolution récente du système financier internacional, Villetaneuse, Université de Paris XIII, Ph.D. thesis.

(1999): Abertura do sistema bancário brasileiro ao capital estrangeiro, in M.C.P. Freitas (ed.), Abertura externa e sistema financeiro, São Paulo, Administrative Development Foundation/Foundation for Support and Research of the State of São Paulo/Institute of Applied Economic Research (FUNDAP/FAPESP/IPEA).

Freitas, M.C.P. and D.M. Prates (1999): Captação de recursos externos, in M.C.P. Freitas (ed.), Abertura externa e sistema financeiro, São Paulo, Administrative Development Foundation/Foundation for Support and Research of the State of São Paulo/Institute of Applied Economic Research (FUNDAP/FAPESP/IPEA).

Goldestein, M. and P. Turner (1996): Banking Crisis in Emerging Economies: Origins and Policy Options, BIS economic paper, No. 46, Basle, Basle Committee on Banking Supervision, October.

Griffith-Jones, S. (1996): The Mexican peso crisis, CEPAL Review, No. 60, LC/G.1943-P, Santiago, Chile, ECLAC.

Gurría, J. (1997): Fluxos de capital: o caso do México, in R. Ffrench-Davis and S. Griffith-Jones (eds.), Os fluxos financeiros na América Latina: um desafio ao progresso, Rio de Janeiro, Editora Paz e Terra.

KPMG Peat Marwick (1998): Pesquisa internacional sobre indústria bancária e de seguros, São Paulo, Federação Brasileira das Associações de Bancos, September.

Machinea, J. L. (1996): La crisis financiera argentina de 1995: causas, características y lecciones, Buenos Aires, mimeo.

Meyer, A. (1997a): Notas sobre a economia argentina, Brasilia, Ministério da Fazenda, Secretaria de Assuntos Internacionais, mimeo.

(1997b): Notas sobre a economia mexicana, Brasilia, Ministério da Fazenda, Secretaria de Assuntos Internacionais, mimeo.

Palomino, A. (1997): Surgimiento y desarrollo de los grupos financieros en México, "Financiamiento del Desarrollo" series, No. 41, Santiago, Chile, ECLAC.

Prates, D. M. (1997): Abertura financeira $e$ vulnerabilidade externa: a economia brasileira na década de 90, Campinas, Brazil, State University at Campinas, Institute of Economics, Master's thesis. (1999): Investimentos de portfólio no mercado financeiro doméstico, in M.C.P. Freitas (ed.), Abertura externa e sistema financeiro, São Paulo, Administrative Development Foundation/Institute of Applied Economic Research (forthcoming).

Rozenwurcel, G. and R. Fernández (1994): El fortalecimiento del sector financiero en el proceso de 
ajuste: el caso argentino, in R. Frenkel (ed.), El fortalecimiento del sector financiero en el proceso de ajuste: liberalización y regulación, Buenos Aires, Red de Centros de Investigación Económica Aplicada.

Skiles, M. (1991): Stabilization and Financial Sector Reform in Mexico, Research Paper No. 9125, New York, Federal Reserve Bank of New York.

Souza, F. (1993): O novo regime cambial brasileiro $e$ suas consequências para a política econômica, Texto de Discussão IPEA, No. 18, Brasilia, Institute of Applied Economic Research (IPEA), November.

Taylor, R. (1997a): Back from the brink, The Banker, London, FT Finance, August.

(1997b): Surfing a rising tide, The Banker, London, FT Finance, August.
(1999): Peso fights back, The Banker, London, FT Finance, February.

The Banker (1997a): Latin notes: Mexico ends bank subsidies; Brazil opens up, London, FT Finance, October.

- (1997b): Latin notes: Competition heats up in Brazil; consolidation continues in Argentina, London, FT Finance, September.

(1998): Top 1,000 world banks, London, FT Finance, July.

The Economist (1997): Flexionando os músculos na América Latina, London, The Economist Newspaper Limited, 11 July.

(1998): Europe's lovesick bankers, London, The Economist Newspaper Limited, 10 January.

Warner, A. (1995): On the Lima trail, The Banker, London, FT Finance, October.

(1998): Latin fever catches on, The Banker, London, FT Finance, January. 